DOI: $10.17516 / 1997-1370-0330$

УДК 81’37(512.157)

\title{
Semantic Development of the Word "Tanara” in Sakha (Yakut) Language
}

\author{
Evdokiia N. Afanaseva and Raissa P. Ivanova* \\ Mirny Polytechnic Institute (branch) of \\ Ammosov North-Eastern Federal University \\ Mirny, Russian Federation
}

Received 28.08.2018, received in revised form 12.09.2018, accepted 26.09.2018

\begin{abstract}
The article is devoted to the evolution of the lexical meaning of the word 'tanara' in Sakha (Yakut) language. The study focuses on Humboldt's activity theory and observes a fusion of cultures as one of the ways of language development. The results of the study can be formulated as follows: etymology and functioning of the word in the epic reveal the following meanings: 'heaven', 'deity', 'spirits of aiyy' and 'ičči'. The word use context has changed under the influence of the Orthodox dogma. Though the external form remained unchanged, the word underwent significant morphological and semantic changes: the affixation method increased the word-formative and phraseforming potential of the word, the basic meaning of 'god' was fixed, the semantic volume was expanded, some values reflecting the pagan world view became obsolete. There was a separation between its synonym 'ičči' being a designation for otherworldly entities, and 'aiyy' as the name of good spirits, which still remains a component of the name of the Christian Orthodox god, 'Aiyy Tayara'.
\end{abstract}

Keywords: semantics, lexical meaning, the word tayara, seme, semantic feature, semantic modification, shift of meaning.

Research area: philology.

Citation: Afanaseva, E.N., Ivanova, R.P. (2022). Semantic development of the word "tanara" in Sakha (Yakut) language. J. Sib. Fed. Univ. Humanit. soc. sci., 15(3), 306-313. DOI: 10.17516/1997-13700330 .

\footnotetext{
(C) Siberian Federal University. All rights reserved

* Corresponding author E-mail address: raissa1@yandex.ru; lukow@mail.ru ORCID: 0000-0002-4373-9441 (Afanas'eva); 0000-0002-9757-1779 (Ivanova) 


\section{Introduction}

Humboldt's activity theory presents language as a dynamic process of thinking and communication. So, language is an important tool for expressing human thought, which manifests itself in communication: "Die Sprache wird durch Sprechen gebildet" (Humboldt, 2000: 163). As a social phenomenon, language is sensitive to different historical changes. According to Humboldt's conception, fusion of cultures is considered to be one of the ways of language development. The problem of linguistic contacts and their impact on the worldview of people was studied in our previous work (Afanas'eva, Ivanova, 2016).

Bloomfield lists the following basic ways of semantic change in a language: specialization and generalization of the word meaning (after H. Paul), obsolescence and loss of meaning, isolation, borrowing and metaphorization. Semantic change can be internally or externally motivated. Changes in the objective reality are determined by the real situation of communication. Alteration in the mental space influences the word context and its sphere of use (Bloomfield, 1968: 478-486). The phenomena of language change, linguistic models, grammaticalization, social context, contact-based explanations and typological perspective, namely: formal and functional motivation for language change (Newmeyer, 2004), metaphors, models and language change (Aitchison, 2004), grammaticalization (Lightfoot, 2004), in cognitive linguistics (Shitikov, 2012), in Russian literature studies (Azarenko, 2013) were discussed in the book "Motives for Language Change" (2004). In the present work, we observe the semantic change as a result of external changes of social and ideological nature.

\section{Etymology and functioning of the word in olonkho epos}

The Sakha noun 'tayara' goes back to the ancient Turkic language: täyri '1. sky, 2. god, deity, 3. divine, 4. master, lord' (DTS, 1969: 544). In the ancient Turkic language there were other designations of sky, with other meaning than 'god, deity': qalïq '1. sky, heavens; airspace, air, 2. heavenly; airy, 3. the upper chambers, the upper floor of the palace; chambers,

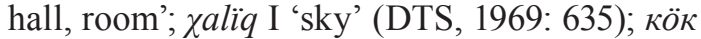
I 'sky' (DTS, 1969: 312), pair words кӧк qalïq 'sky, heavens' (DTS, 1969: 312, 412; Sravnitel'no-istoricheskaia grammatika..., 2001: 59). In Sakha language küöx xallaan 'blue sky' is a combination of the adjective küöx and the noun xallaan. In this case, we see traces of contamination of the meaning of the noun kök I and the adjective kök VI 'blue, bluish', kök täyri 'blue sky' (DTS, 1969: 312). Ancient Turkic names of heavenly bodies kün 'sun' and aj 'moon' bear the meaning of 'god': kün tänri lit. 'god the sun' (DTS, 1969: 326, 544); aj tänri rel. 'the deity of the moon' (DTS, 1969: 24, 544). In Sakha language there is no designation of $\ddot{z} y$ tanara, but in some set phrases there are signs of the deification of the sun and the moon. The combination of kün tayara 'the sun-god' was later transformed into kün ïraaxtaayy lit. 'the sun king' (king after the arrival of Russians, lit. ̈̈raaxtaayy 'staying in a remote place'). The seme of the sun and moon deification has been preserved in the imperative set combination kün-ïy buol! 'Save! Be the sun and the moon!' These examples show the stability of the semantic structure of words representing the significance of god. Semantic signs of the ancient Turkic word meanings can still be found in some set phrases. The sky and heavenly bodies were endowed with a divine nimbus; a man sought salvation from them.

In the Sakha olonkho epos "Žuluruyar Nyurgun Bootur" ("Nyurgun Bootur the Swift") the lexeme tayara is used in the meaning of 'sky':

Tayara syrdyyta, / Tatyiyk yllyyta, / Kün taxsyyta, / Küöregey kötüüte ... (گ̌NB, 2003: 178-179). 'At dawn [of the sky], when the tit sings at sunrise, when the lark flies off...'

In Olonkho, the noun xallaan is found in the composition of the izafat combination xallaan tayarata, 'heavenly god, the celestial' and the attributive combination tayaralaax xallaan, 'the sky is the abode of gods'. According to Olonkho, the sky is the habitat of not only the divine, but also the demonic forces of $x a l$ laan abaahita 'heavenly demons, demons' (Afanas'eva, 2013: 78). 
Tayaralaax xallaanym / taxsan erer künün / tunalyanin kurduk ... (亏̌NB, 2003: 13). '... it looks like the radiance of the rising sun of the divine sky'.

Tayara is a deity name. The supreme celestial deity appears in the form of the grayhaired old man:

Uruy Aiyy / Aar Toyon tayara ('the white holy God'), which is toyus hallaan toyono, arys hallaan yraahtaayyta, sette hallaan kineehe (KKK, 1985: 1420) 'the lord of the nine heavens, the king of the eight heavens, the prince of the seven heavens'.

The epithets aiyy and aar in the meaning of the 'saint, kind, revered' have correspondences in the ancient Turkic language, cf. other Turkic. ayïr II 1. 'valuable, dear, 2. respected, honoured, respectable, honourable; the holy one' (DTS, 1969: 19); arï III '1. clean, uncontaminated, 2. fig. morally impeccable, noble, decent, unblemished', 3. Rel. 'pure, true, uncomplicated, righteous, sacred, holy' (DTS, 1969: 51-52). Aiyy is a characteristic of the names of saints and good spirits.

The epos reflects the worship of the sky, the worship of the heavenly deities. The hero of the Olonkho "Er Sogotox" ("Lonely Warrior"), presenting the cup with koumiss, appeals to the supreme heavenly deity with the request:

Warrior Er Sogotox on his knees / He went down, stared at the sky, / began to create the spell with choron: / "O Great Heavenly Host, / Yuryun Aar, the great ruler / of the nine white tiers of the sky ..." (Er Sogotox, 1991).

Apparently, the set combination tayara tabata 'divine deer' refers to the archaic cult of the deer sacrificed in honour of the gods. Often this combination is used as an epithet for the bride. The next quotation refers to a richly dressed young bride, whose hand and heart shall be fought for by the strongest warriors of the middle and lower worlds:

Tayara tabatyn kurduk / Tayïnnaran naynalïttygyt / Tahaara oxson kuluy! Kïaybyt ïlya, / Kïaytarbyt matya (క̌NB, 2003: 315). 'Dress her as a divine deer, bring her out quickly! The winner takes her, and the loser gets nothing'.

Olonkho displays an animistic world full of spirits, where every phenomenon is endowed with a living soul, every object has the spirit of $i c ̌ c i$, compare with ancient Turk. i $i \delta i$ 'lord' (about god) (DTS, 1969: 203), igä 'master, spirit, deity' (DTS, 1969: 204), ijä 'host, lord (about god)' (DTS, 1969: 205). In the following examples, the word tayara is used as a synonym for the noun $i \check{c} \check{c} i$ 'spirit, master':

Uot Kudulu Bayyalym / Uluu kuday tayarata, /

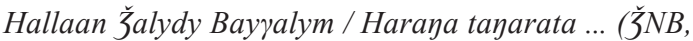
2003: 174). 'The great deity of the fiery ocean Kudulu, the dark deity of the heavenly ocean of Jalidi';

Etymological and contextual analysis reveals the following semantic features: 'the sky', 'the sky is a deity', 'the sky is the abode of celestial gods', 'deities are spirits'. The words tayara 'heaven, deity', aiyy 'holy', ičči 'spirit' form a single synonymic row. The outer and inner forms of the lexeme tanara indicate the presence of some animistic view and traits of the ancient religion of Tengrism. Human life is controlled by the inhabitants of heaven and spirits, so the man asks them for help and blessing, offers them sacrifices.

\section{Word meaning development after the spread of Christianity}

"Yakut Language Dictionary" by E.K. Pekarskiy reflects the lexical composition of the language of the $19^{\text {th }}$ century and, besides linguistic information, offers some cultural information of encyclopaedic nature. It provides five lexical meanings of the word tayara; the semantic volume of the word is expanded by extrapolating the primary meaning to all concepts associated with god. In the dictionary article, the $3^{\text {rd }}, 4^{\text {th }}$ and $5^{\text {th }}$ meanings are later formations that appeared after Christianization: tayara '1) the visible sky; sky as a deity' bylyttaax tayara 'cloudy sky, cloudy day, cloudy weather'; aiyy tayara (in the old days) 'the deity sky; 2) the general name of good creatures (= ajyy), a good spirit, a god, a goddess, a pagan deity; the chief deity who lives in the seventh 
heaven; spirit protector; idol, fetish; image of the protector spirit'; 3) 'God; deity, divine nature; icon, image', tayarata suox 'godless, atheist'; Aiyy Tanara; cress tayara 'crucifixion'; üs mörsüönneeh tayara 'The Holy Trinity'; ürdük tayara 'the Supreme Being'; tayara aha 'holy gifts'; 4) 'holy, sacred', tayara uи 'holy water'; 5) 'holiday'; ulaxan tayara 'a great holiday' (e.g. Christmas); tayara kün (tayara küne) 'a festive day, a feast; Sunday' (Pekarskiy, 1959: 2552). The image of the ancient deity of the Sakha Aiyy toyon tayara acquires some icon features, and Orthodox icons are called tayara külüge lit. 'shadow of God'.

In the Christianization period, the Orthodox dogma influence changed the context of the word use, shifting the emphasis towards the meaning of "God". Along with this, the morphological processes of affixation began.

With the help of the affix -laax, which carries the meaning of possession, the lexeme tanaralaax was formed. In the function of the attribute it conveys the information that a baptized person is considered to be enlightened and advanced: tanaralaax 'divine' (about communion), ünär tanaralaax, üysär suuttaax kihi 'a person who has a deity to whom he prays, and a court in which he is judged' (i.e. social and moral, not savage). Language retains traces of early beliefs; each Sakha clan, or ulus, had its totem deity: oyus tayaralaax (shaman) 'with the bull deity (protector)'; kuba tayaralaax uluus 'ulus with the swan deity', moyotoj tanaralaax nähiliek 'the settlement with the chipmunk deity' (Pekarskiy, 1959: 2552). Idolatry is illustrated by the phrase: oloror oyo saya taas tayaralaayym 'a stone idol of a sitting child [size] I had'. In shamanism, spirits retain their national identity: nuис́са tayaralaax shaman 'to whom the Russian devil comes during the ritual', toyus tayaralaax 'shaman to whom the Tungus spirit comes' (Pekarskiy, 1959: 2552). The patronage of the gods extends to all living beings: tayaralaax sü̈hü buolla 'this is a domestic animal that is not destined at this time to die or be stolen and eaten (about a cow that escaped from thieves)' (Pekarskiy, 1959: 2553).

Examples with the affix -lyy carrying the meaning of similarity, in the function of the adjective mainly designates church rituals: tajaralyy kičäl 'divine endeavour'; tayaralyy sibätiäydänär ‘divine sanctification' (Pekarskiy, 1959: 2553). With the help of affixes -msax, -hyt, nouns are formed, denoting the conviction and status of a person as a believer: tayaramsax 'God-loving, worshiper'; tayarahyt 1) 'having God's fear, God-fearing, pious, praying, carrying God within him; a hypocrite, a saint', tayarahyttar 'church as a society'; 2) 'devoutness' (Pekarskiy, 1959: 2553).

Earlier, death was perceived as a withdrawal from the middle world: orto doyduttan bar - 'leave the middle world' (Pekarskiy, 1959: 2552). After the adoption of Christianity, in the interpretation of death another motive appeared; after that, dying meant 'going to God'. The idea of going to God was one of the significant moments in changing the image of God; dying, a person does not disappear into the dark world of demons, but reaches the saving God. The meaning is expressed with the help of the verbal affix - laa: tayaralaa 'to rest, to die; to give up the spirit', tayaralaabyt 'the dead' [Pekarskiy 1959: 2552].

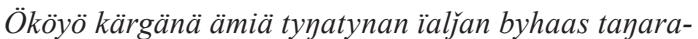
laabyt suraxtaaya. Sofron Danilov. 'They say that Okoj's wife died of lung disease this spring' (BTS, 2013: 210).

The dictionary of E.K. Pekarsky reflects both pre-Christian and Christian concepts of God. The pagan god meant heaven, spirit, deity, idol, fetish and totem. Christianity, which began to spread in Yakutia in the $17^{\text {th }}$ century, brought new meanings to the semantics of the word tayara. The appearance of words describing church life testifies to the role of the church in the process of transforming the pagan concept of God. In the context of Orthodoxy, the word tayara takes on some new meanings: 'god', 'holy', 'icon', 'day of church holidays'. Affixation expands the word-formation capacity; the word performs the functions of an adjective, a verb, forms derivative nouns. The word $i c ̌ c r i$ falls out of the synonymic row, retaining its reference to the otherworldly forces in general, while aiyy remains an epithet of the god name Aiyy Tayara. The activ- 
ities of the Orthodox Church contributed to the transformation of the value component of spiritual life. God tayara materializes in the form of an iconic image; all Orthodox saints are categorized as gods.

The modern "Great Explanatory Dictionary of Yakut Language" (2013) provides five meanings of tayara as a noun.

1. According to religious beliefs: 'the supreme being who created the world and controls it, God'. Tayarattan kördös 'ask from God' (BTS, 2013: 203).

Taクara kinileri [aanñallary] olus taptyyr buolan, ürdä suox üörüünü, muүura suox jolu bäläxtääbit. N. Luginov. 'God gave them [the angels] boundless joy and endless happiness, because he loves them';

2. The icon.

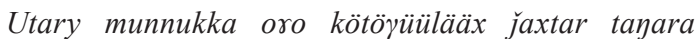
oloror. Amma Aččygyia. 'In the opposite corner, the goddess sits with a child in her arms' (BTS, 2013: 204);

3. The day celebrated by the church as a religious holiday.

Mäxääläyäp tayara tiiyen kelbite. Kunnuk Uurastyyrap. 'Soon, St. Michael's day came';

4. Archaism. 'protector spirit, totem';

5. Archaism. 'sky'.

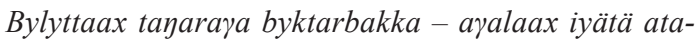
axtatan üöskäppitter. P.Oyuunuskay. 'Father and mother brought her up in tenderness, not showing her the cloudy sky' (BTS, 2013: 204).

The lexeme tayara is a component of the terminological combination, which generally refers to God in general: tajara itäyälä 'religion', 'a religion based on the belief in the existence of god (in the form of the God-man) who created the world and rules it' (BTS, 2013: 207), lit. 'God's faith'.

The dictionary entry tayara and the examples from fiction texts show the shift of the main meaning as a result of the shift the actualization of the meaning of the god. The meanings of 'heaven', 'protector spirit', 'totem' have passed into the category of archaisms, and the meanings formed under the influence of Orthodoxy, have established: 'icon', 'saints' day', 'church feast'.

\section{The meanings of phraseological units with 'tayara' component}

Semantic analysis of the phraseological units with tayara component helps to identify some additional semantic features. Christianity was perceived by the Sakha through the pagan cult experience; by analogy with deification of the sun and the moon, the Sakha later compared Christ to the sun: tayara (kun) kurduk körör 'to deeply respect smb., to bow before someone; idolize' (Nelunov, II, 2002: 179).

God is the supreme almighty being, and the man is powerless before him: tayaraya mastammykka dyly (mastan) 'brave in front of an enemy too strong' (Kulakovsky) (about impotent threat), lit. 'it's like a stick to threaten the sky':

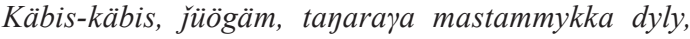
jylyabïtïgar baaysan da xayïaxpytyi? Onohuubut onnuk buollaya äbäät. N. Luginov. 'No, no, dear, it's just like threatening the sky with a stick, you cannot change anything, complaining about fate? So, we have such a fate' (Nelunov, II, 2002: 178).

God knows and sees everything: tayara biler 'God knows' (BTS, 2013: 205).

Xanna siljaryn tanara biler. 'God knows where he goes' (Nelunov, II, 2002: 178).

A person tries to be honest with God:

Tanara baaryna, kyrǰyk. A. Aččygyia. 'God knows, it's true' (Nelunov, II, 2002: 177).

God disposes of the destinies of people and man obeys him: tayara xanna gynarynan syljabyt 'whereever God sends'.

Tayara xanna gynarynan syljabyt. 'Wherever God sends, we'll go there' (BTS, 2013: 207).

The church is the abode of God: tayara jiete 'building for worship, the church, the temple of God', tayara üöreve 'theology', tayara dolbuura (xoloruga) 'a shelf for icons'. The communion rites serve as a motivator for phraseological units: tayaraya tikser kurduk (keriete) 'seldom, occasionally' from tayaraya tigis 'religion, confession, communion' (Nelunov, II, 2002: 180; BTS, 2013: 206); tayara ahyn 
kurduk tut - 'to cherish smth. very much, to cherish smth., lit. treat smth. as a prosphora!' (Nelunov, II, 2002: 177).

God's grace is perceived as a carefree life, devoid of suffering: tayara taalata inform. 'a joyful, free life', tayara talbyt 'to be on top of bliss'.

Tuox da kihalyata, äräye suox, bäyäte talbytynan ja-

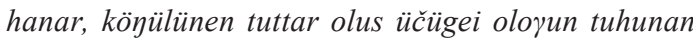
"kööčöön körö", "tayara taalata" dien noruokka bylyr etillen xaalbyt (Nelunov, II, 2002: 180). 'Since immemorial times, people have referred to a carefree, devoid of suffering, independent and free life as the "merriment under the sun", "God's grace".'

God is the saviour and man can always rely on God's help: tayara buol - 'protect, save, protect from encroachments' (lit. 'be a god'), tayara byyhaatyn 'God save', tayara kömölöhüex 'God will help', tayara ahan bierder 'if God helps, lit. if God opens the way' (BTS, 2013: 206).

Tayara kömölöhöö ini, - dien oyonnor kiriestenen kebiste. P. Oyuunuskay. 'I think God will help, "the old man said and crossed himself", (Nelunov, II, 2002: 179).

God is merciful, the man hopes for the pity of God: tayara ahymmyt 'God was merciful'.

Seriitten xasta da ulaxannyk baahyran kelbite. Xayaan tyynnaax orputa buolla, čaxčy tanara ahymmyt kihite. 'He returned from the war with multiple heavy wounds. How could he survive? The truth is, God took pity on him' (Nelunov, II, 2002: 177).

Everything that a person has in this world is given by God: tayara bierie loan phrase: 'god will give', tayara tugu bierbitinen loan word: 'what god sent', tayara uon оссс́опи bierie 'god will render a hundredfold, lit. God will give ten times more', tayara bäläye 'a gift of fate (god)' (BTS, 2013: 205-208; Nelunov, II, 2002: 178-180).

Tayara äyiexe uon oččony bierie, onon, xata, malyymanna yllat. S. Omolloon. 'God will reward you with a hundredfold, therefore, come on, serve a prayer'.
God can punish a person: tayara nakaaha 'punishment of God', tayara atayastaabyt loan phrase: 'god offended someone by smth'.

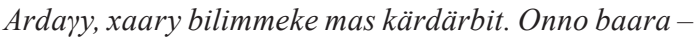
tayara nakaaha dien. 'We felled the trees, despite the rain and snow. It was God's punishment' (BTS, 2013: 207).

The language reflects a reverential attitude towards God, he should be thanked: tayaraya maxtal 'thank God' (BTS, 2013: 206). A person feels a mental connection with him: tayara sanaa bierdeyine 'something good will come to mind suddenly (lit. if God sends a thought)' (BTS, 2013: 207), tayara imnännäye 'god ordered (lit. probably god winked)' (BTS, 2013: 206).

A disobedient person, who does not recognize God, is despised: tayarany umnubut bayayi 'a person who does not obey and violates God's laws'. Some phraseological units have stylistic shades, expressing irony, reverence and humour. The ironic attitude towards those who create themselves an idol is transmitted by the phraseological unit tanara gynan

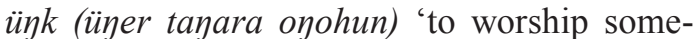
one' (BTS, 2013: 206). Some comparative units express respect and reverence: tanara kurduk körör 'deeply respect smb., bow to smb., idolize (lit. as to look at God)'.

Saya oskuolany tuttarbyt. Onon oloxtooxtor Nikolai Vasilievihy tanara kurduk köröllör äbit. N. Bosikov. 'He built a new school. Therefore, local residents look at Nikolai Vasilyevich as a god' (BTS, 2013: 206-207).

Most phraseological units are borrowed from Russian language, which motivates the following semes: the 'higher being', 'disposes of the destinies of living beings', 'saviour and helper', 'brings grace', 'all-knowing', 'giving', 'gracious', 'punishing'.

\section{Conclusion}

The material and spiritual culture of the Sakha people takes its origin from the era of the ancient Turks, as evidenced by the historical connection of the words of Ancient 
Turkic täyri and Sakha tayara. Analysis of the linguistic material indicates that the ideology of Orthodox Christianity, which spread among the people of Sakha more than three hundred years ago, caused some significant transformations in the language system. As a result, the following changes occurred in the development of the lexeme tayara in Sakha language:

1) due to the metonymic shift, it lost its primary meaning of 'heaven';

2) the meaning of 'God' was updated;

3) the semantic volume expanded by extending the meaning to the designation of Christian saints, shrines and relics;

4) affixation discovered new functional and semantic possibilities; the word has acquired the functions of an adjective, a verb, and some new nouns have been derived;
5) adoptions from Russian language increased the phrase-forming potential of the word;

6) with the differentiation of meanings between the words tayara "god" and ičc $i$ "spirit", the latter acquired a meaning close to the designation of otherworldly forces, e.g. iččileex sir 'a place inhabited by dark forces'.

Most of the set units are borrowed from Russian language through adoption. This process was influenced by the following circumstances: 1) translation of religious books and texts by Orthodox missionaries, 2) religious service in Sakha language, and 3) development of bilingualism among the local population. Analysis shows that changes have affected all levels of the language. Linguistic facts prove that the transition from the pre-Christian pagan time to the Christian era led to some transformations in the concept of God.

\section{References}

Afanas'eva, E.N. (2013). Reprezentatsiia kontsepta «Nebo» v kartine mira iakutskogo iazyka [Representation of the Concept of "Sky" in the Picture of the World of Yakut Language]. In Izvestiia RGPU im. A.I. Gertsena [Herzen Russian State Pedagogical University Newsletter], 160, 75-84. Saint Petersburg.

Afanas'eva, E.N., Ivanova, R.P. (2016). The Sakha and the Evenk: Fundamentals of Common Conceptual Space. In Journal of Siberian Federal University. Series: Humanities, 9 (10), 2298-2304.

Azarenko, N.A. (2013). Eksplikatsiia i implikatsiia kontseptov BOG i D'IAVOL v tekste romana F.M. Dostoevskogo "Prestuplenie i nakazanie" [Explication and Implication of the Concepts of GOD and DEVIL in the Novel "Crime and Punishment" by F.M. Dostoevsky]. In Voprosy kognitivnoy lingvistiki [Cognitive Linguistics Matters], 4 (037), 61-68.

Bloomfield, L. (1968). Iazyk [Language]. Translated by E.S. Kubryakova, V.P. Murat. Moscow, Progress, $606 \mathrm{p}$.

BTS - Saxa tylyn byhaaryylaah ulahan tyld'yta [Great Explanatory Dictionary of Yakut Language] (2013). Ed. by P.A. Sleptsova. Novosibirsk: Nauka.

DTS - Drevnetiurkskiy slovar' [Old Turkic Dictionary] (1969). Ed. by V.M. Nadeliaev, D.M. Nasilov, E.R. Tenishev, A.M. Shcherbak. Institute of Linguistics off the Academy of Sciences of the USSR. Leningrad: Nauka.

Er Sogotoh. Iakutskoe skazanie [Er Sogotoh. Yakut legend] (1991). In Sibirskie skazaniia [Siberian legends]. Transl., Trans. and entry by A. Prelovsky. Moscow: Sovremennik, P. 329-394.

Humboldt, W. (2000). Izbrannye trudy po iazykoznaniiu [Selected Works in Linguistics]. Translated by G.V. Ramishvili. 2nd edition. Moscow: Progress, 400 p.

KKK - Kuruubaj Xaannaah Kulun Kullustuur. Iakutskoe olonkho. Skazitel' I.G. Timofeev-Teplukhov [Kuruubaj Xaanaah Kulun Kullustuur. Yakut Olonkho Epos. Storyteller I.G. Timofeev-Teplukhov] (1985). Moscow: Glavnaia redaktsiia vostochnoy literatury izd-va «Nauka», 605 p.

Motives for Language Change (2004). Edited by Raymond Hickey. Cambridge University Press. 286 p.

Nelunov, A.G. (2002). Iakutsko-russkiy frazeologicheskiy slovar' [Yakut-Russian Phraseological Dictionary]. Vol. II. Novosibirsk: Publishing House of the Siberian Branch of the Russian Academy of Sciences.

Pekarskiy, E.K. (1959). Slovar' iakutskogo iazyka [Yakut Language Dictionary]. Vol. III. St. Petersburg: Academy of Sciences of the USSR, 3858 p. 
Shitikov, P.M. (2012). Religioznaia metafora v svete kognitivnoy lingvistiki [Religious Metaphor in the Light of Cognitive Linguistics]. In Voprosy kognitivnoy lingvistiki [Cognitive Linguistics Matters], 3 (32), 40-42.

Sravnitel'no-istoricheskaia grammatika tiurkskikh iazykov. Leksika [Comparative-Historical Grammar of Turkic Languages. Vocabulary] (2001). 2nd ed., ext. / ed. by E.A. Potseluevsky, responsible. ed. E.R. Tenishev. Moscow: Nauka. 822 p.

亏̌NB - 亏̌ulurujar N'urgun Bootur: Olonho [Nurgun Boorur the Swift: Olonkho] (2003). Institute for the Humanities Research. Yakutsk.

\title{
Развитие семантики слова 'тангара' в якутском языке
}

\author{
Е.Н.Афанасьева, Р.П. Иванова \\ Политехнический институт (филиал) \\ Северо-Восточный федеральный университет \\ им. М.К. Аммосова в г. Мирном \\ Российская Федерачия, Мирный
}

\begin{abstract}
Аннотация. Статья посвящена изучению эволюции лексического значения слова 'танара' в якутском языке. Рассматривается этимология, функционирование слова в эпическом тексте, проводится анализ данных толковых и фразеологических словарей, выпущенных в разное время. Слово 'танара' восходит к древнетюркскому täyri и до XX века сохраняет значение 'небо, божество'. Внешняя и внутренняя формы лексемы свидетельствуют о наличии следов древних языческих верований (тэнгрианства, шаманизма). Поздние словари фиксируют значения, отображающие реалии православного христианства и замену первичного значения на 'бог', значение ‘небо’ отходит на второй план. Значения, обозначающие ранние верования, перешли в ранг устаревших. Бог больше не тождественный духу в языческом понимании, a персонифицированный иконический образ. Изменение контекстуального окружения слова привело к активизации аффиксов, что способствовало образованию глагола, имени прилагательного и других имен существительных. Заимствования из русского языка увеличили фразообразовательный потенциал слова; большинство фразеологических единиц с компонентом 'танара' образованы способом калькирования. Анализ показал, что изменения семантики слова 'танара' коснулись всех уровней языка. Семантические преобразования обусловлены внешними факторами, влиянием русской культуры через распространение среди якутов православного религиозного учения.
\end{abstract}

Ключевые слова: семантика, лексическое значение, слово 'танара', сема, семантический признак, семантическая модификация, изменение значения.

Научная специальность: 10.00.00 - филологические науки. 